\title{
Treatment of the lateral patellar luxation in toy poodles
}

\author{
Tratamento da luxação lateral da patela em poodles toy
}

\author{
João Guilherme Padilha Filho ${ }^{1}$ Francisco de Assis Dórea Neto ${ }^{3}$ \\ Hélia Cristina Dórea ${ }^{2}$ Rodrigo César Sanches ${ }^{2}$ Júlio Carlos Canola $^{1}$
}

\begin{abstract}
The purpose of this retrospective study was to report the occurrence of lateral patellar luxation in poodles. The animals were referred to the Orthopedics Service of the Veterinary Hospital, Faculdade de Ciências Agrárias e Veterinárias, Jaboticabal Campus, São Paulo, Brazil, twelve client-owned poodles, seven females and five males poodles ranging in age from three to nine months. Clinical examination showed lameness, pain and deformities of the affected limbs. Surgical trochleoplasties were performed with medial retinacular overlap and medial tibial tuberosity transposition. The animals recovered their normal activity within a period of one to two weeks after surgery. Although this was a rarely occurring pathological condition in poodles, surgical repair was easy to execute because of its similarity to correction of medial patellar luxation. Lateral patellar luxation in small dogs is rare and, when present, is of congenital origin, at times progressing to marked functional impotence of the affected limbs.
\end{abstract}

Key words: stifle joint, patellar luxation, dog.

\section{RESUMO}

O objetivo deste estudo retrospectivo foi relatar a ocorrência de luxação lateral em poodles. Os animais foram encaminhados ao Serviço de Ortopedia do Hospital Veterinário da Faculdade de Ciências Agrárias e Veterinárias, Campus de Jaboticabal, SP/Brasil, doze poodles, sete fêmeas e cinco machos, com idades variando entre três a nove meses. Ao exame clínico, notaram-se sinais de dor, claudicação e deformidades físicas dos membros afetados. Realizaram-se procedimentos cirúrgicos de condroplastia com sobreposição medial de retalho do retináculo e a transposição medial da crista tibial. O retorno à função do membro afetado ocorreu em um período de uma a duas semanas de pós-cirúrgico. Apesar de ser condição patológica rara em poodles, a reconstituição cirúrgica foi de fácil execução pela similaridade desta com a correção para luxação medial de patela. A luxação lateral de patela é rara em cães de raça pequena, e quando presente, é de origem congênita, podendo progredir para marcante impotência funcional dos membros afetados.

Palavras-chave: joelho, luxação patelar, cão.

\section{INTRODUCTION}

Femoropatellar instability is a common cause of lameness observed in small animal clinics (VASSEUR, 1993; HULSE, 1995). In small dogs, medial patellar luxation is the most commonly diagnosed type of congenital or developmental luxation (VASSEUR, 1993). However, lateral patellar luxation is seldom observed in these animals and, when present, it is of congenital origin, possibly progressing to marked functional impotence of the affected limbs (VASSEUR, 1993; HULSE, 1995; PIEMATTEI \& FLO, 1997). In large or giant dogs, luxation is normally lateral and causes a syndrome associated with severe manifestations of hip dysplasia including marked limb deformity (VASSEUR, 1993; HULSE, 1981; REMEDIOS, 1992; ROUSH, 1993; TOMLINSON \& CONSTANTINESCU, 1994; MCLAUGHIN, 1996).

The clinical signs associated with patellar luxations include pain, intermittent or continuous

${ }^{1}$ Veterinary College, São Paulo State University (UNESP), Jaboticabal, SP. Brazil. E-mail: Padilha@fcav.unesp.br.

${ }^{2}$ Veterinary College. Universidade Metropolitana de Educação e Cultura (UNIME), Lauro de Feitas, BA, Brazil. Av.Luiz Tarquínio Pontes, 600, Jaboticabal, SP, Brasil. E-mail: dorea.oria@terra.com.br.

${ }^{3}$ Veterinary College São Paulo University, UNESP, Jaboticabal, SP, Brazil. Universidade Metropolitana de Educação e Cultura (UNIME), Lauro de Feitas, BA, Brazil. Av.Luiz Tarquínio Pontes, 600, Jaboticabal, SP, Brasil. 
lameness and pathological changes involving bones and adjacent tissues (MCLAUGHIN, 1996; PIEMATTEI \& FLO, 1997). Lateral patellar luxation is a disorder characterized by excessive anteversion of the femoral neck, coxa valga, hypoplasia of the vastus medialis, medial bowing of the femur and tibia (genu valgum), external foot rotation, and bent posture with altered gait (VASSEUR, 1993; HULSE, 1995, PIEMATTEI \& FLO, 1997). The purpose of the study is to report the occurrence of lateral patellar luxation in poodles.

Twelve poodles, seven females and five males, ranging in age from 3 to 9 months and weighing 2 to $6 \mathrm{~kg}$ were referred to the Orthopedics Service of the Veterinary Hospital, Faculdade de Ciências Agrárias e Veterinárias, UNESP, Jaboticabal Campus, SP, Brazil, among the years from 1999 to 2002. The major complaints were lameness, deformity of the pelvic limbs and altered gait. The history showed that all animals had been presenting the problem since the time when they were acquired by their owners.

Upon clinical examination, lameness was found to be grade two to five (SUMNER-SMITH, 1993). Seven animals were bilaterally affected and supported their body weight on the thoracic limbs. Five animals were unilaterally affected, three with the right hindlimb and two with the left hindlimb, transferred their weight to the contralateral limb. The degrees of luxation ranged from three to four in bilaterally affected dogs and from two to three in unilaterally affected dogs. The animals exhibited pain, severe muscle atrophy in the affected limbs angular deformities of the femur and tibia and external foot rotation of the extremity with lateral dislocation and shortening of the quadriceps musculature and the gastrocnemius tendon. The animals with bilateral luxation showed bent posture and altered gait.

To minimize the effects of muscle shortening, physiotherapy procedures were scheduled one or two weeks before and after the surgical procedure. The protocol consisted of daily passive movement massage, and elongation by immobilization with a Schroeder-Thomas splint during the night.

The joint was approached through a lateral parapatellar incision. During inspection of the joint, the absence of the trochlear sulcus and deformity of the lateral epicondyle were observed (Figure 1A). The surgical treatment consisted of troclear chondroplaty with the method of cartilaginous flap and, medial tibial tuberosity transposition. For the troclear condroplasty, besides the medial retinacular overlap. The cartilage was outlined using a number 15 scalper (Figure 1B), and separated from the subchondral bone with the aid of a Freer periosteal elevator (Figure 1C). A new trochlear sulcus was created with the aid of a Luer ronguer and a small trochlear rasp. As the sulcus reached a depth sufficient to accommodate the patella, the cartilage flap was replaced to its original bed and the patella was repositioned.

Medial transposition of the tibial tuberosity was performed with the aid of a small hand saw and its fixation with a screw concerning $2 \mathrm{~mm}$ and $14 \mathrm{~mm}$ in length (Figure 1D, 1E). After reposition of the patella, the defect created on the lateral surface of the femur was covered by an autograft from the medial retinaculum (Figure $1 \mathrm{E}$ ). The capsule, retinaculum, subcutaneous tissue, and the other planes were sutured with rontine fashion, using naylon 3-0 on the capsule, poliglactin 910 on the retinaculum in interrupted simple pattern. (Figure 1F).

Medical postoperative consisted of carprofen $^{\mathrm{a}} 1 \mathrm{mg} \mathrm{kg}^{-1} \mathrm{PO}$, BID for 10 days, butorphanol, ${ }^{\mathrm{b}}$ $0.1 \mathrm{mg} \mathrm{kg}^{-1}$ IM, SID for three days, and cephalexin ${ }^{\mathrm{c}}$ was administered orally at the dose of $30 \mathrm{mg} \mathrm{kg}^{-1} \mathrm{PO}$, TID for 10 days. The animals were reevaluated every day for one week and weekly during the subsequent three months. The dogs were in good clinical condition throughout the study period.

Upon palpation, the dogs showed moderate pain sensitivity during the immediate postoperative period and discrete sensitivity over the subsequent four days, with pain disappearing on the fifth day. No formation of fistulae or purulent exudates was observed. Bilaterally affected animals were first submitted to surgical intervention on the limb with the greater deformity and, after its function was reestablished on average in two weeks, a similar procedure was carried out on the contralateral limb (Figure 2A, 2B).

Lateral patellar luxation is a frequent finding in large dogs, but is rare in small and toy breeds. In a report of 124 cases of patellar luxation, there was only one small toy breed dog presenting the condition in its lateral form (HAYES et al., 1995). This disease causes a syndrome associated with severe deformities of the limb, with a reserved prognosis (VASSEUR, 1993; ARNOCZKY \& TARVIN, 1996). Prognosis and treatment vary according to the degree of luxation. In the present study, we observed that the degree of luxation does not depend on animal age. However, with advancing age and permanence of the injury, the deformities tend to progress (PIEMATTEI \& FLO, 1997).

The limb deformities observed in the present study were similar to those described in the literature for large and giant dog breeds (VASSEUR,

Ciência Rural, v.35, n.4, jul-ago, 2005. 


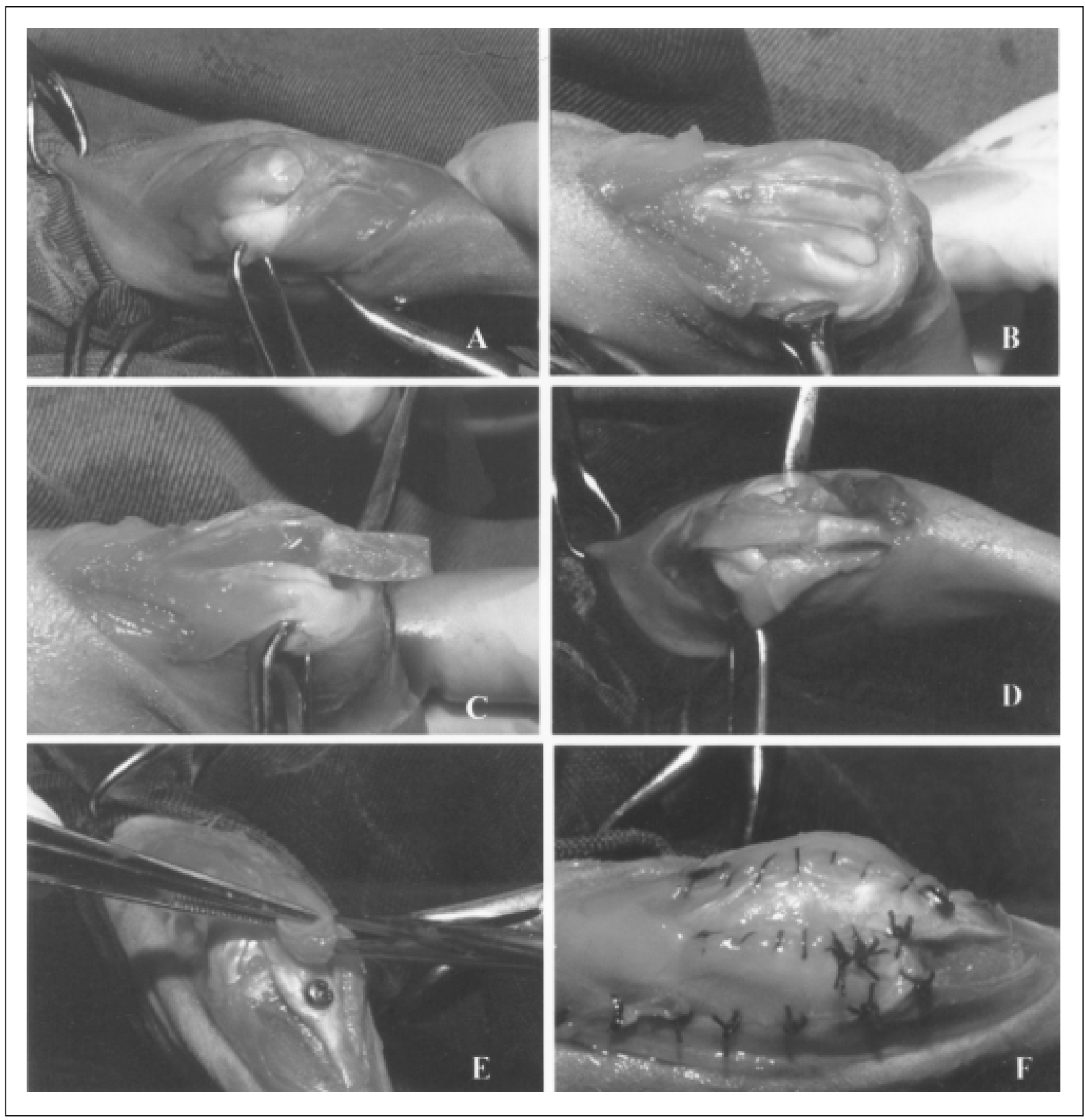

Figure 1 - Photographic image of the surgical procedure for the correction of lateral patellar luxation. Observe the absence of the trochlear sulcus (A), the trochleoplasty procedure (B), the elevation of the retinacular flap with the formation of a new trochlear sulcus (C), accommodation of the patella in the new trochlear sulcus after medial tibial tuberosity transposition (D), medial retinacular overlap (E), and retinacular suture $(\mathrm{F})$.

1993; ARNOCZKY \& TARVIN, 1996; PIEMATTEI \& FLO, 1997). This condition results from lateral misalignment and compromises the extensor mechanism forcing the thigh outwards, laterally dislocating the tendon of the quadriceps and promoting internal femoral torsion, distracting of the medial fascia, contraction of the lateral fascia, external rotation, and lateral deviation of the proximal tibia
(HULSE, 1995). The cause of lateral patellar luxation is still unknown but the condition is believed to be related to abnormal anteversion or coxa valga of the hip joint (HULSE, 1995).

The surgical technique used for the animals reported here was similar to that used for the correction of medial luxation (HULSE, 1995). Medial tibial tuberosity transposition was used to reestablish the 


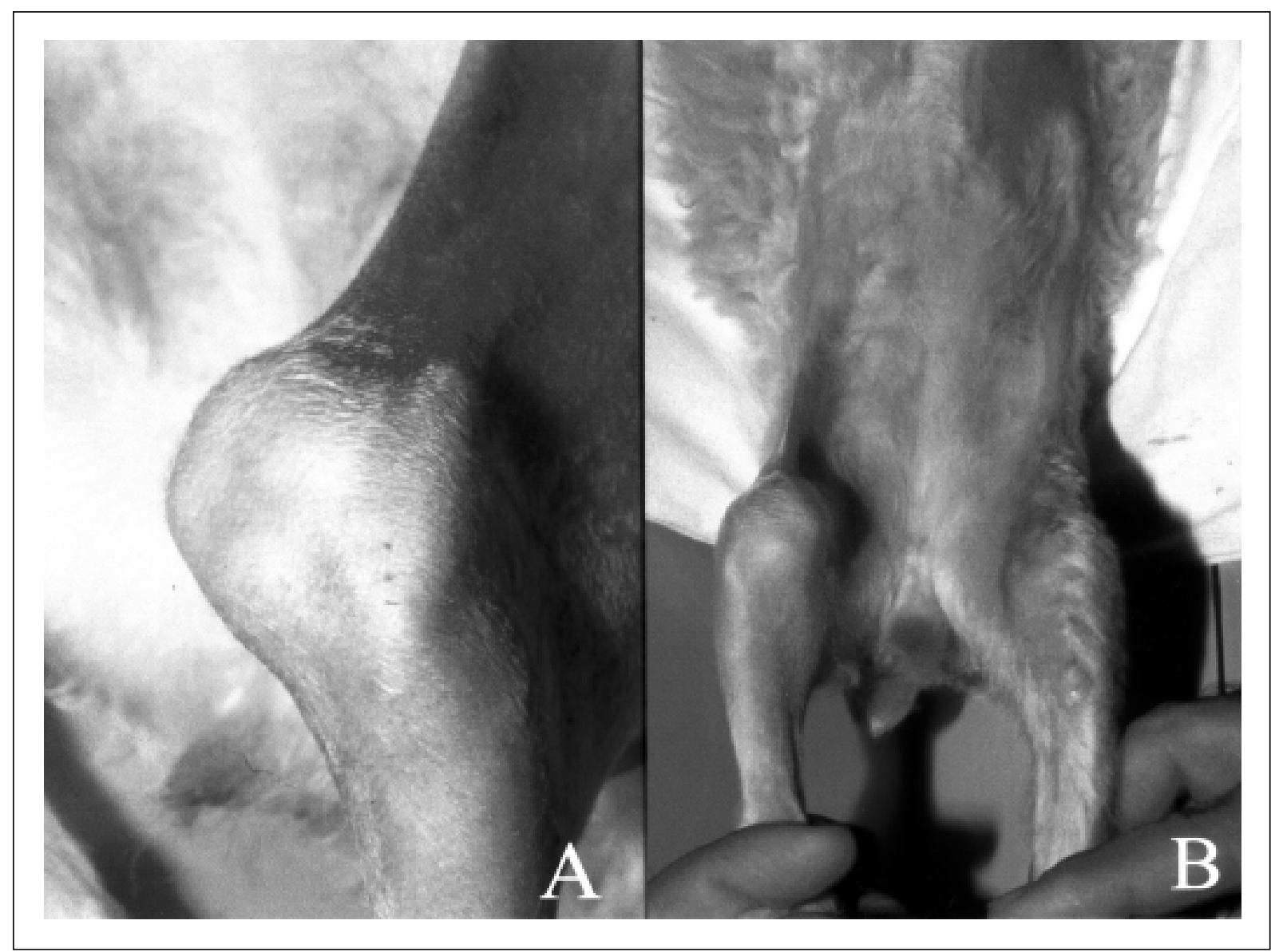

Figure 2 - Photographic images of the animal with bilaterally lateral patellar luxation grade IV. Preoperative evaluation of the left hindlimb. Note the difficulty in the extension of the stifle joint and severe muscular atrophy (A). Two weeks after the correction of lateral patellar luxation in the left hindlimb. Note the difference in extension between the right and left stifle joints (B).

alignment of the thigh extensor mechanism related to the quadriceps musculature (VASSEUR, 1993; MCLAUGHIN, 1996; PIEMATTEI \& FLO, 1997). Trochleoplasty was used to promote patellar stability in the femoral trochlea and to permit realignment of the extensor mechanism. This is a simple technique that can be used in dogs younger than six months (VASSEUR, 1993). Due to the fact that adhesion of cartilage to the subchondral bone in older animals prevents cartilage dissection (HULSE, 1995). Although this technique has been used in animals even to nine months, it was not observed larger difficulties, because the cartilage was not still totally adhered to the bone subchondral as referred for HULSE (1995).

The trochleoplasty was performed with the objective of deepen the trochlear sulcus of the affected animals, as recommended by HULSE (1981). The use of a cartilage piece was reinforced by An experiment (FLO, 1969) in which the histological behavior after surgery of the articular cartilage and subcondral bone were evaluated. Following the same purpose BARROS (2001) described that the hystological evaluations have union by regeneration between subchondral bone and cartilage flap, vitality of the cartilage flap and healing between the flap and the non-dissected cartilage.

The implemented physiotherapy in the cases were necessary due to the shortened quadriceps muscles and of the gastrocnemius tendon. The massage therapy applied over those muscles have provided a relief of the existing contraction enabling the use of the SchroederThomas splint. This method of immobilization used only during night time have provided a stretching of the referred muscles, without interfering on the articular movement, besides facilitating the repositioning of the patella in the surgery procedure. This protocol have also been adopted in the postsurgery period, which provided a faster return of the 
animals to their daily and normal activities as described by CARVALHO et al. (2001).

Although this was a rarely occurring pathological condition, surgical repair was easy to execute because of its similarity to correction of medial patellar luxation. It could be pointed out that physiotherapy prior to the procedure it could have been a feasible maneuver of importance by promoting muscle elongation during the preoperative period, facilitating the surgical procedure and leading to early limb rehabilitation.

\section{SOURCES AND MANUFACTURES}

a. Rimadyl $\AA^{\circledR}$ - Pfizer

b. Turbogesic $\AA$ - Fort Dodge

c. EMS -Generic medicine

\section{REFERENCES}

ARNOCZKY, S.P.; TARVIN, G.B. Reparo cirúrgico das luxações e fraturas patelares. In: BOJRAB, M.J. Técnicas atuais em cirurgia dos pequenos animais. 3.ed. São Paulo, SP : Roca, 1996. p.670-677.

BARROS, M.T. Comportamento da cartilagem articular em cães submentidos à trocleoplastia do fêmur pela técnica do retalho cartilagíneo. Estudo Experimental. 2001. 49f. Dissertação (Mestrado em Cirurgia Veterinária) - UNESP.

CARVALHO, G. et al. Tratamento de luxação lateral e medial da patela com fisioterapia: relato de 15 casos. Ciência Animal, v.11, suplemento.1, p.249, 2001

FLO, G.L. Surgical correction of a deficient trochear groove in dogs with severe congenital patellar luxations utilizing a cartilage flap and subchondral grooving.
1969. 64f. Dissertation (Master's of the Surgery) - Michigan State University, Michigan.

HAYES, A.G. et al. Frequency and distribution of medial and lateral patellar luxation in dogs: 124 cases (1982-1992). J Am Vet Med Assoc, v.57, n.1, p.105-109, 1995.

HULSE, D.A. Pathophysiology and management of medial patellar luxation in the dog. Vet Med Small Anim Clin, v.76, n.1, p.43-51, 1981

HULSE, D.A. The stifle joint. In: OLMESTEAD, M.L. Small animal orthopedics. St. Louis, MA : Mosby, 1995. p.395-403.

MCLAUGHIN, R. Treatment of patellar luxations. In: THE NORTH AMERICAN VETERINARY CONFERENCE, 10., 1996, Orlando. Proceedings... Orlando Fl : Easterm States Veterinary Association, 1996. p.417.

PIEMATTEI, D.L.; FLO, G.L. Brinker, Piermattei, and Flo's handbook of small animal orthopedics and fracture repair. 3.ed. Philadelphia, PA : Saunders, 1997. p.516-534.

REMEDIOS, A.M. et al. Medial patellar luxation in 16 large dogs: a retrospective study. Vet Surg, v.21, n.1, p.5-9, 1992.

ROUSH, J.K. Canine patellar luxation. Vet Clin North Am Small Anim Pract, v.23, n.4, p.855-868, 1993

SUMNER-SMITH G. Gait analysis and orthopedic examination. In: SLATTER, D.H. Textbook of small animal surgery. 2.ed. Philadelphia, PA : Saunders, 1993. p. $1577-1586$

TOMLINSON, J.; CONSTANTINESCU, G. Repair of medial patellar luxation. Vet Med, v.89, n.1, p.48-56, 1994.

VASSEUR, H.R. The stifle joint. In: SLATTER, D.H. Textbook of small animal surgery. 2.ed. Philadelphia, PA : Saunders, 1993. p.1854-1861. 